\title{
Vaccination of cattle with synthetic peptides corresponding to predicted extracellular domains of Rhipicephalus (Boophilus) microplus aquaporin 2 reduced the number of ticks feeding to repletion
}

\author{
Glen A. Scoles ${ }^{1,2,5^{*}}$ (D), Hala E. Hussein ${ }^{2,3}$, Cassandra L. Olds ${ }^{4,6}$, Kathleen L. Mason ${ }^{1}$ and Sara K. Davis ${ }^{1}$
}

\begin{abstract}
Background: There have been ongoing efforts to identify anti-tick vaccine targets to protect cattle from infestation with cattle fever ticks Rhipicephalus (Boophilus) microplus. Two commercial vaccines based on the tick gut protein Bm86 have had variable effectiveness, which has led to poor acceptance, and numerous studies have attempted to identify vaccine antigens that will provide more consistently effective protection. Transcriptomic analysis of $R$. microplus led to identification of three aquaporin genes annotated to code for transmembrane proteins involved in the transport of water across cell membranes. Previous work showed that vaccination with full-length recombinant aquaporin 1 (RmAQP1) reduced tick burdens on cattle. Targeted silencing of aquaporin 2 (RmAQP2) expression suggested it might also be a good anti-tick vaccination target.
\end{abstract}

Methods: Three synthetic peptides from the predicted extracellular domains of RmAQP2 were used to vaccinate cattle. Peptides were conjugated to keyhole limpet hemocyanin $(K L H)$ as an antigenic carrier molecule. We monitored the antibody response with ELISA and challenged vaccinated cattle with $R$. microplus larvae.

Results: There was a $25 \%$ reduction overall in the numbers of ticks feeding to repletion on the vaccinated cattle. Immune sera from vaccinated cattle recognized native tick proteins on a western blot and reacted to the three individual synthetic peptides in an ELISA. The vaccinated calf with the highest total IgG titer was not the most effective at controlling ticks; ratios of IgG isotypes 1 and 2 differed greatly among the three vaccinated cattle; the calf with the highest lgG1/lgG2 ratio had the fewest ticks. Ticks on vaccinated cattle had significantly greater replete weights compared to ticks on controls, mirroring results seen with RNA silencing of RmAQP2. However, protein data could not confirm that vaccination had any impact on the ability of the tick to concentrate its blood meal by removing water.

Conclusions: A reduced number of ticks feed successfully on cattle vaccinated to produce antibodies against the extracellular domains of RmAQP2. However, our predicted mechanism, that antibody binding blocks the ability of RmAQP2 to move water out of the blood meal, could not be confirmed. Further study will be required to define the

*Correspondence: glen.scoles@usda.gov

1 USDA-ARS, Animal Disease Research Unit, Washington State University, Pullman, WA, USA

Full list of author information is available at the end of the article permits use, sharing, adaptation, distribution and reproduction in any medium or format, as long as you give appropriate credit to the original author(s) and the source, provide a link to the Creative Commons licence, and indicate if changes were made. The images or other third party material in this article are included in the article's Creative Commons licence, unless indicated otherwise in a credit line to the material. If material is not included in the article's Creative Commons licence and your intended use is not permitted by statutory regulation or exceeds the permitted use, you will need to obtain permission directly from the copyright holder. To view a copy of this licence, visit http://creativecommons.org/licenses/by/4.0/. The Creative Commons Public Domain Dedication waiver (http://creativeco mmons.org/publicdomain/zero/1.0/) applies to the data made available in this article, unless otherwise stated in a credit line to the data. 
mechanism of action and to determine whether these vaccine targets will be useful components of an anti-tick vaccine cocktail.

Keywords: Aquaporin, Cattle tick, Bm86, lgG isotype, Anti-tick vaccine

\section{Background}

The cattle tick Rhipicephalus (Boophilus) microplus causes both direct and indirect injury to livestock worldwide. Direct injury due to tick feeding results in significant production losses and damage to hides. Indirectly, Boophilus ticks are vectors of several globally important pathogens causing anaplasmosis and babesiosis, which result in significant morbidity and mortality [1]. Acaricide use is the most common means of tick control to prevent both direct and indirect injury; however, acaricides are expensive, can result in residues in meat and dairy products, may cause environmental contamination, and resistance has developed to several classes of acaricides [2]. It has been suggested that vaccines would be the most effective and environmentally sound approach for the prevention and control of ticks and tick-borne pathogens [3]. Early development of the concept of controlling ticks by vaccination centered on attempting to understand the phenomenon of naturally acquired antitick immunity [4]. However, naturally acquired immunity is not sufficient to prevent damage and disease transmission, and the idea of targeting concealed antigens as anti-tick vaccines was proposed [5]. The observation that vaccination of cattle with the concealed "Boophilus microplus" tick midgut antigen Bm86 could reduce tick burdens led to efforts to develop commercial anti-tick vaccines. Although Boophilus microplus has been reclassified as Rhipicephalus microplus [6], the Bm86 protein has retained the original "Bm" designation. The first Bm86 vaccine, TickGARD ${ }^{\mathrm{TM}}$ (Hoechst Animal Health; Australia), was developed and marketed in Australia [7], and later Gavac ${ }^{\mathrm{TM}}$ (Heber Biotec; Havana, Cuba), also based on Bm86, was developed in Cuba [8] and marketed in Latin America [9]. However, neither of these vaccines has been a sustained commercial success. TickGARD ${ }^{\mathrm{TM}}$ is no longer on the market and $\mathrm{Gavac}^{\mathrm{TM}}$ has limited availability. The limited commercial success of vaccines based on Bm86 was primarily due to market considerations driven by variable effectiveness against different tick populations, and the need for frequent boosts to maintain effective levels of immunity [10]. Because these commercially available vaccines reduce, but do not eliminate, the need for acaricides, they were intended to be incorporated into an integrated management strategy which also includes the use of acaricide, albeit at a reduced frequency $[1,9]$. The development and use of a new generation of anti-tick vaccines is an emerging alternative means for tick control [3, 11-14]. Research efforts are ongoing to identify anti-tick vaccine targets that will be more consistently effective than Bm86 has been [14], and several tick antigens including $R$. microplus glutathione-S transferase, ubiquitin, selenoprotein W, elongation factor 1-alpha, aquaporins, subolesin, and others have been proposed as potential vaccine candidates for use alone or in combination with Bm86 [3, 14].

Aquaporins are a family of integral transmembrane proteins that are broadly conserved across taxa. The proteins that make up the transmembrane aquaporin channel are responsible for active movement of water and solutes across cell membranes [15]. Ticks concentrate their blood meal by actively moving water out of the gut and returning it to the host via saliva [16] using active transport mechanisms such as aquaporins. Aquaporins have been proposed as good anti-tick vaccine candidates because water balance is a critical biological activity for blood-feeding ticks and because there are exposed extracellular domains on aquaporin proteins that could be easily targeted to block water channel function. Hypothetically, antibody binding to extracellular domains of aquaporins in the tick gut and salivary glands could abrogate aquaporin function, reducing the ability of the tick to actively concentrate the blood meal and reducing the volume of saliva the tick can inject back into the host. This should lower the protein content of the blood meal, which would reduce fecundity and could also interfere with interactions at the host-parasite interface that are mediated by saliva, such as immunosuppression, histamine binding, and anticoagulation [17, 18].

Three aquaporin cDNAs have been identified in transcriptomic studies of $R$. microplus $[19,20]$. When aquaporin 1 (RmAQP1) was expressed as a full-length protein and tested in a vaccine trial, it resulted in significant protection against feeding ticks [21]. Targeted gene silencing studies with aquaporin 2 (RmAQP2) [22] resulted in reduced tick survival and increased replete weights, suggesting that ticks were less able to remove excess water from the blood meal [22]. Vaccination targeting aquaporin proteins of other tick species has shown similar effects [23, 24].

Structural modeling suggests that RmAQP2 has surface-exposed extracellular domains that contain predicted B-cell epitopes [22]. In the current study we tested the hypothesis that vaccination of cattle with synthetic peptides designed from expressed sequences 
representing these extracellular domains would induce production of antibodies that reduce tick feeding success and fecundity by interfering with the critically important biological functions of aquaporin in the tick.

\section{Methods}

\section{Cattle and ticks}

All animal use was approved by the University of Idaho Institutional Animal Care and Use Committee (IACUC, protocol \#2016-27). Six age-matched male Holstein calves were acquired from the University of Idaho dairy. Calves were $\geq 2$ months of age with $\geq 80 \mathrm{~kg}$ body weight at the start of the study. This cohort of cattle had no previous exposure to $R$. microplus, since the tick does not occur in the United States north of the quarantine zone along the border with Mexico. Animals were randomly assigned to either the control or vaccine group (three per group) and vaccinated according to the protocol described below. At the end of the vaccination protocol, cattle were moved to individual moated concrete block stalls for the tick challenge. For the tick challenge (see below) the La Minita strain of $R$. microplus was used. This tick colony originated from an outbreak tick population in Star County, Texas [25, 26], and has been maintained continuously (3-4 generations per year) at the Animal Disease Research Unit tick lab at the University of Idaho since it was acquired from Texas.

\section{Peptides}

Three peptide sequences from the predicted extracellular domains of the protein coded for by the RmAQP2 gene (GenBank accession numbers: protein ALJ75650, DNA
Sequence KP406519) have been described previously [22]. Peptide 1 was modified from the previously published sequence by adding four additional amino acids to encompass a predicted B-cell epitope and possibly increase its antigenic potential (AVFQLGSVGLAAAP). The amino acid sequences of peptides 2 and 3 were as described previously (\#2: ADALSQVDVNLAIVYGTNATAPVFSCFPAPGV, \#3: MCGWGSAVFSFRSYNWFWV) [22]. Peptides were commercially synthesized (New England Peptide, Gardner, MA, USA) and supplied either as free peptide or conjugated to carrier molecules. For vaccination, peptides were conjugated to keyhole limpet hemocyanin (KLH) as a carrier to stimulate immune response. For use in enzyme-linked immunoassay (ELISA; see below) peptides were conjugated to bovine serum albumin (BSA). KLH-conjugated peptides were supplied lyophilized and were initially dissolved by adding 50:50 dimethyl sulfoxide (DMSO)/phosphatebuffered saline (PBS), then taken to $1 \mathrm{mg} / \mathrm{ml}$ concentration with PBS for a final DMSO concentration of $20 \%$. Unconjugated peptides were solubilized by adding 75:25 $\mathrm{DMSO} / \mathrm{sterile}$ water and then taken to a $1 \mathrm{mg} / \mathrm{ml}$ concentration with PBS for a final DMSO concentration of $35 \%$. BSA-conjugated peptides were obtained solubilized in PBS at $1 \mathrm{mg} / \mathrm{ml}$ concentration.

\section{Vaccination protocol}

Cattle were each vaccinated four times at 3-week intervals (days 0, 21, 42, and 63); see Fig. 1 for a graphical representation of the experimental timeline. The initial three vaccinations were done with the peptides conjugated to $\mathrm{KLH}$; the fourth injection (day 63) was with peptides

\section{Days after $1^{\text {st }}$ vaccination}

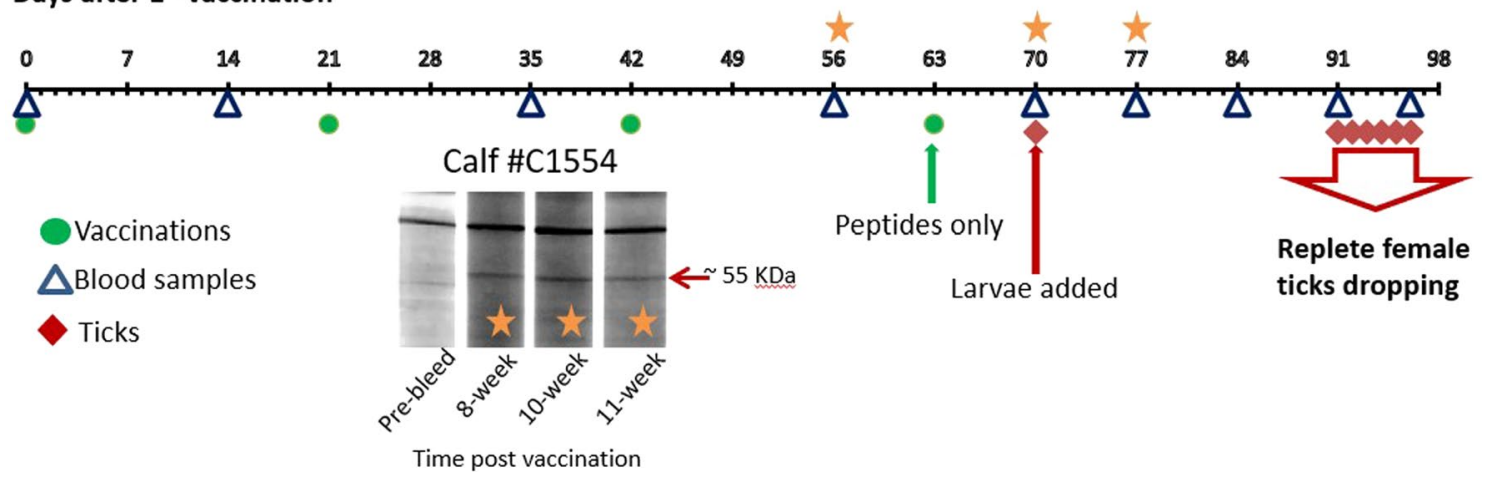

Fig. 1 Timeline of experiment and western blot showing immune response to native tick protein after vaccination with peptides. Timeline represents days, counted from the first vaccination. Green dots represent vaccinations, with the first three vaccinations (days 0,21 , and 42 ) done at 3-week intervals using peptides conjugated to $\mathrm{KLH}$, and the fourth vaccination (day 63) consisting of peptides alone. Blue triangles indicate blood samples taken before the initial vaccination (pre-bleed), 2 weeks after each vaccination, and weekly during the tick feed (days $0,14,35,56,70,77$, 84, 91, 98). Red diamonds indicate dates ticks were placed on (day 70) and collected as detached repletes (days 91-96). Orange stars on the timeline correspond to lanes on the western blot showing reactivity of serum from representative peptide-vaccinated calf $C 1554$, with native tick protein showing reactivity to a 50-55 KDa band in this calf; the other two vaccinated calves showed similar reactivity 
alone, not conjugated to KLH, in order to boost the peptide-specific immune response in the absence of KLH. Each injection consisted of $0.05 \mathrm{mg}$ of a single conjugated peptide and $0.75 \mathrm{mg}$ Quil-A (saponin) adjuvant in a volume of $0.5 \mathrm{ml}$. On the day of vaccination, each animal received three injections, each with a different peptide, at three different injection sites. Individual peptides were mixed with adjuvant by drawing repeatedly through a 21-gauge needle to mix well. All three doses of each peptide were mixed in a single tube, allowing an extra dose for loss in mixing and in the needle $(1 \mathrm{ml} 0.2 \mathrm{mg} /$ $\mathrm{ml}$ peptide plus $1 \mathrm{ml} 3 \mathrm{mg} / \mathrm{ml}$ Quil-A). Each injection was administered subcutaneously at a different injection site to avoid any potential antigenic competition at the draining lymph node (injection sites were left neck, right neck, right flank). The controls were injected with saponin mixed with KLH (MilliporeSigma, St. Louis, MO, USA) alone (no conjugated peptide), in the same way as the KLH conjugated peptides were prepared and injected (i.e., three injections at three different sites).

\section{Tick challenge}

One week after the final peptide boost, the cattle were challenged with larval ticks. A tick-feeding patch was adhered to the back of each calf with cattle hip tag cement as described previously [27], and each patch was infested with $\approx 5000$ larval ticks, which is the approximate number of larvae hatching from $0.25 \mathrm{~g}$ of eggs. Larval ticks were prepared for challenge by weighing aliquots of $0.25 \mathrm{~g}$ of eggs all originating from the same colony rearing; the eggs were from a mixture of egg masses from a large number of females which had all been mixed and weighed on the same day to ensure uniformity. Because $R$. microplus is a one-host tick, larvae will develop through the larval, nymphal, and adult stages on the same host. Feeding patches were opened on days 5 and 9 postapplication to assess attached larvae and newly molted nymphs, respectively, as they progressed through stages of feeding and development. After replete females began to detach at about day 20, the patches were opened daily, and all repletes that had dropped in the previous 24-h period were removed. Daily collections were repeated until most ticks had completed feeding; on the final day all remaining attached ticks were removed and counted.

The total number of detached replete (fully fed) ticks collected each day was recorded. A random sample of up to 72 ticks each day were weighed and saved in individual wells of 24-well tissue culture plates. On days when there were fewer than 72 ticks, all were weighed and saved. Saved ticks were held for egg production, and when all oviposition was complete, egg mass weights were recorded. A subsample of eggs from up to 48 of these ticks per day was set aside individually to assess hatching rate. A daily sample of 10 replete females from each calf was saved for protein determination (see below). All remaining ticks were discarded after they were counted.

\section{Antibody titers}

To assess antibody titers and to determine what titers the ticks were actually exposed to, blood samples were taken from cattle before the first vaccination (pre-bleed) and 2 weeks after each subsequent vaccination, then weekly once the tick challenge began (days $0,14,35,56$, $70,77,84,91$, and 96). Blood was collected in red-top Vacutainer tubes and allowed to clot before being centrifuged to separate serum. An ELISA was developed to track antibody titers in response to vaccination. Nunc Polysorp 96-well flat-bottom immuno-plates (Thermo Scientific, Rochester, NY, USA) were coated with BSAconjugated peptides. Each BSA-conjugated peptide was diluted to $0.02 \mathrm{mg} / \mathrm{ml}$ in carbonate-bicarbonate coating buffer (4 mM Na2CO3, 9 mM NaHCO3, pH 9.4); $50 \mu \mathrm{l}$ of this peptide working solution was added to each well and held overnight at $4{ }^{\circ} \mathrm{C}$ to coat the wells with approximately $1 \mu \mathrm{g} /$ well of peptide available to bind. Plates were washed five times by hand with $1 \times \mathrm{PBS} / 0.05 \%$ Tween-20 to remove unbound peptide after coating, then blocked with $225 \mu \mathrm{l} /$ well of $1 \times$ PBS/0.05\% Tween-20 plus $5 \%$ BSA (blocking buffer) for $2 \mathrm{~h}$.

Diluted samples $(50 \mu \mathrm{l})$ were added to the plates in triplicate wells and allowed to incubate for $1 \mathrm{~h}$ at room temperature. Unbound primary antibody was removed by washing five times by hand with $1 \times$ PBS/0.05\% Tween20 , and $50 \mu \mathrm{l} /$ well of a 1:500 dilution (in blocking buffer) of goat anti-bovine IgG $(\mathrm{H}+\mathrm{L})$ antibody-horseradish peroxidase (HRP) conjugate (Life Technologies, Frederick, MD, USA) was applied for $1 \mathrm{~h}$ at room temperature. Unbound secondary antibody was removed by washing five times by hand with $1 \times$ PBS/0.05\% Tween-20. Plates were developed with SigmaFast OPD (MilliporeSigma, St. Louis, MO, USA) and read at $450 \mathrm{~nm}$ on a SpectraMax 190 microplate reader (Molecular Devices, San Jose, CA, USA).

Using the ELISA described above, we determined that a 1:256 dilution was optimal for use across all the available sample time points to show the change in antibody levels during the study. To determine the peak titers, the sample point with the highest antibody response at 1:256 for each peptide was chosen, and twofold serial dilution series of the serum samples from this day were tested to find the lowest dilution where the 95\% confidence intervals for the pre-bleed and the test sample did not overlap. The reciprocal of the dilution at this point was considered to be the maximum antibody titer. 


\section{Measurement of bovine lgG1 and IgG2 using ELISA}

Isotyping was completed similarly to the protocol above, with the difference that the secondary antibodies were un-conjugated and an additional HRP conjugate was used for detection. Specifically, the secondary antibodies were mouse anti-bovine IgG1 or mouse anti-bovine IgG2 (Bio-Rad Laboratories, Hercules, CA, USA) and the HRP conjugate was goat anti-mouse IgG $(\mathrm{H}+\mathrm{L})$ (Life Technologies, Frederick, MD, USA).

\section{Protein content of replete female ticks}

A random sample of 10 replete females were collected from each calf on each day after the ticks began dropping for a total of 6 days ( 60 ticks) from each calf. After weighing, replete female ticks were placed individually in tubes with $2 \mathrm{ml}$ protein lysis buffer solution containing $0.05 \mathrm{M}$ Tris, 0.005 M EDTA, 1\% NP-40, and protease inhibitors (cOmplete $^{\mathrm{TM}}$, Mini, EDTA-free Protease Inhibitor Cocktail, Roche, MO, USA), and frozen at $-20{ }^{\circ} \mathrm{C}$. In preparation for the assay, tubes were thawed, the tick bodies were punctured with a 16-gauge needle, and the tissues and solution were drawn into an attached 3-ml syringe approximately 15 times to thoroughly homogenize each sample. An aliquot of $200 \mu \mathrm{l}$ was taken from each sample and centrifuged at $8000 \mathrm{rpm}$ to pellet unlysed material (cuticle, tissue fragments, etc.), and $10 \mu \mathrm{l}$ of the supernatant was diluted in $490 \mu \mathrm{l}$ sterile water. Triplicate samples of $25 \mu \mathrm{l}$ of each dilution were analyzed for total protein concentration using the Pierce BCA Protein Assay according to the manufacturer's protocol (Thermo Scientific). A 1:50 dilution of protein lysis buffer above with sterile water was used as a diluent for the BSA standard curve. Completed plates were incubated at $37{ }^{\circ} \mathrm{C}$ for $30 \mathrm{~min}$ and read at $562 \mathrm{~nm}$ on a SpectraMax 190 microplate reader (Molecular Devices, San Jose, CA, USA). The basis for comparison between populations of ticks from vaccinated versus control cattle was total soluble protein as measured by the assay as a proportion of total tick weight.

\section{Western blots}

Ovaries from fed female $R$. microplus (3-4 days and replete) were dissected, placed in RNAlater solution (Thermo Fisher Scientific, Waltham, MA, USA), and stored at $-80{ }^{\circ} \mathrm{C}$. To prepare protein for the western blot, samples were thawed and RNAlater was carefully pipetted off the tissues. Protein lysis buffer (0.05 M Tris, 0.005 M EDTA, 1\% NP-40, cOmplete ${ }^{\mathrm{TM}}$ mini EDTA-free protease inhibitor cocktail; Roche, MO, USA) was added to the tissues according to the manufacturer's instructions. Tubes were sonicated using a cup horn (Fisherbrand Model 705, Thermo Fisher Scientific) for $6 \times 15 \mathrm{~s}$ at $100 \%$ power and cooled on ice between steps. The prepared samples were then analyzed using a Qubit 3 Fluorometer (Thermo Fisher Scientific) to determine protein concentration, and $25 \mu \mathrm{l}$ of a 1:10 dilution of replete female ovary protein was prepared to run on a NuPage 4-12\% Bis-Tris gel $(1.0 \mathrm{~mm} \times 10$ wells, Thermo Fisher Scientific) by adding $12.5 \mu \mathrm{l}$ NuPage $4 \times$ LDS loading buffer, $5 \mu \mathrm{l}$ NuPage $10 \times$ sample reducing agent, and 7.5 $\mu \mathrm{l}$ sterile water. The mixture was vortexed and heated in a dry block at $70{ }^{\circ} \mathrm{C}$ for $10 \mathrm{~min}$. A 20-gauge $1 / 2$-inch needle was used to carefully remove pre-cast lane dividers between four wells of the gel to form one large well. The gel was then secured in the Mini Gel Tank (Thermo Fisher), $1 \times$ NuPage MOPS buffer containing antioxidant was added to the inner chamber, and the same buffer without antioxidant was added to the outer chamber. Ovary protein was pipetted into the large open well of the gel, and a mixture of $2.5 \mu \mathrm{l}$ PageRuler ${ }^{\mathrm{TM}}$ Plus pre-stained and $2.5 \mu$ MagicMark ${ }^{\mathrm{TM}}$ XP western ladder (both Thermo Fisher Scientific) was pipetted into a separate adjoining single well. Electrophoresis was completed for $\sim 50 \mathrm{~min}$ at a constant $200 \mathrm{~V}$.

The proteins were then transferred to a nitrocellulose membrane using the iBlot gel transfer stack (Thermo Fisher Scientific) and Program PO (20 V for $1 \mathrm{~min}, 23 \mathrm{~V}$ for $4 \mathrm{~min}, 25 \mathrm{~V}$ for $2 \mathrm{~min}$.) The membrane was blocked with $1 \times$ Tris-buffered saline (TBS) $+0.1 \%$ Tween$20+5 \%$ non-fat milk for $1 \mathrm{~h}$ at room temperature. Equal strips were cut from the blocked membrane, serum from calves was diluted $1: 1$ in $1 \times \mathrm{TBS}+0.1 \%$ Tween- $20+10 \%$ non-fat milk and incubated with the membrane strips for $2 \mathrm{~h}$ at room temperature, rocking side to side gently. After primary incubation was completed, the strips were washed in $1 \times \mathrm{TBS}+0.1 \%$ Tween-20 twice immediately and then three times for $5 \mathrm{~min}$ each. Goat anti-mouse IgG (H+L)-HRP antibody (Thermo Fisher Scientific) was diluted $1: 5000$ in $1 \times$ TBS $+0.1 \%$ Tween- $20+5 \%$ non-fat milk for the ladder lane and control strip. Rabbit anti-bovine IgG (whole molecule)-HRP antibody (MilliporeSigma, St. Louis, MO, USA) was diluted 1:2000 in $1 \times \mathrm{TBS}+0.1 \%$ Tween-20+5\% non-fat milk for the bovine serum strips. Membrane strips were incubated with the secondary antibody dilutions for $1 \mathrm{~h}$ at room temperature, rocking gently. After secondary incubation was completed, the strips were washed as described above. Prometheus ProSignal Pico (Genessee Scientific, San Diego, CA, USA) components were prepared 1:1 for imaging the blot. Enhanced luminol solution was added to stabilized peroxide solution, mixed, and placed on the washed strips for $2 \mathrm{~min}$. Strips were drained of excess reagent, arranged in a blot development folder, and imaged using a ChemiDoc XRS System (Bio-Rad Laboratories, Hercules, CA, USA). 


\section{Analysis of data}

Tick data (number and weight of replete females, weight of egg masses, and egg hatching, average protein content, etc.) were collected daily and summarized as the average for that day for each calf. The daily averages were combined as a single value for each animal across the full 6 days the ticks were dropping, and the values for the three vaccinated and three control animals were compared using Student's $t$-test (implemented in Microsoft Excel).

\section{Results \\ Timeline for vaccination, serum sampling, and tick application}

Figure 1 presents a timeline for the experiment including the days of vaccination (days $0,21,42$, and 63), the days bovine serum samples were collected for determination of antibody titers (days 0, 14, 35, 56, 70, 77, 84, 91, and 96 ), and the days ticks were applied and collected (larvae applied day 70, replete ticks dropping days 91-96). All vaccinated and control cattle tolerated the vaccinations well and there were no adverse reactions at the injection sites; however, our animal health records from the experiment suggest that one of the vaccinated calves, C1551, suffered from failure to thrive and had lower weight gain than the other five calves. After the last day of tick drop, a final serum sample was collected and cattle were all euthanized (day 96).

\section{Bovine immune response to native tick protein}

Antibody from the vaccinated cattle bound to tick protein isolated from the ovary of engorged female ticks on a western blot. Although serum from vaccinated and unvaccinated cattle bound to many different tick proteins on the blot, there was one clear ovary protein band at approximately $50-55 \mathrm{kDa}$ that was bound only by serum from vaccinated cattle and was not bound by either prebleed serum or serum from control (unvaccinated) animals. All vaccinated cattle produced antibody that bound to this band; a representative blot for vaccinated calf C1554 is shown in Fig. 1.

\section{Antibody titers}

To compare the antibody titers of all samples over the course of the experiment from pre-bleed through the end of the tick feeding, all sera were tested in the ELISA using a serum dilution of 1:256 with blocking buffer (Fig. 2 and Additional file 1: Data file S1). To determine the peak titer for each calf against each peptide, we selected the day that the average response to the 1:256 dilution was the highest and tested a full twofold serial dilution series on serum from that sample point. The average titer at
1:256 was the highest at week 8 for peptide 1 , week 10 for peptide 2 , and week 8 for peptide 3 . The inverse of the greatest dilution before all reactivity was lost was considered the maximum antibody titer (Table 1 and Additional file 2: Data file S2). The relative amounts of IgG isotypes IgG1 and IgG2 were determined for each peptide for each calf at the same time points as the maximum antibody titers (Table 2, Fig. 3, and Additional file 3: Data file S3). All cattle produced more IgG1 than IgG2 (ratio above 1.0). Vaccination with peptide 2 led to greater relative amounts of IgG1. Calf C1554 produced the greatest amount of total antibody (Fig. 2) but had the lowest ratios of IgG1/IgG2.

\section{Tick challenge}

The feeding patches were opened to observe the ticks inside of them on days 5 and 9 after application of the ticks to check for tick attachment and early feeding success. Although tick numbers could not be quantified at these time points, fewer ticks were visible on these days on all vaccinated cattle as compared to the unvaccinated control cattle.

Replete females had begun to detach on the 19th day after larvae were applied (corresponding to day 90 since the first vaccination); starting on tick day 20, the patches were opened daily and all ticks that had detached in the previous 24-h period were removed. All detached ticks were removed from the patches daily through tick day 25; on day 26 of tick feeding, all remaining attached and detached ticks were removed (corresponding to day 96 since the beginning of the experiment when the first vaccinations were given). Vaccinated cattle produced an average of $1201(N=3, \mathrm{SD}=199.8)$ ticks, as compared to an average of $1594(N=3, \mathrm{SD}=61.2)$ ticks for the control group, a statistically significant $24.7 \%$ reduction (one-tailed two-sample $t$-test, $d f=4, P=0.0156$ ). The daily numbers of replete females and average tick weights for each day from each calf can be seen in Fig. 4 and in Tables 3 and 4; the complete data set for all individual ticks is available as Additional file 4: Data file S4.

The average weight of replete ticks from vaccinated cattle was significantly greater than ticks from the control cattle, $M=0.311 \mathrm{~g}(N=3, \mathrm{SD}=0.005)$ vs. $M=0.281 \mathrm{~g}$ $(N=3, \mathrm{SD}=0.014)$, respectively (one-tailed two-sample $t$-test, $d f=4, P=0.0012$ ), a $10.7 \%$ increase (Table 4 and Fig. 4). The average difference in weight between the two groups increased over the time that fully fed adult ticks were dropping; ticks that took a longer time to feed to repletion showed a greater difference in weight between the vaccinated and unvaccinated groups (Table 4). Ticks collected after the first day of drop (tick day 20) from vaccinated cattle averaged $6.36 \%$ heavier than ticks from the control cattle, whereas by the sixth day of drop, ticks 


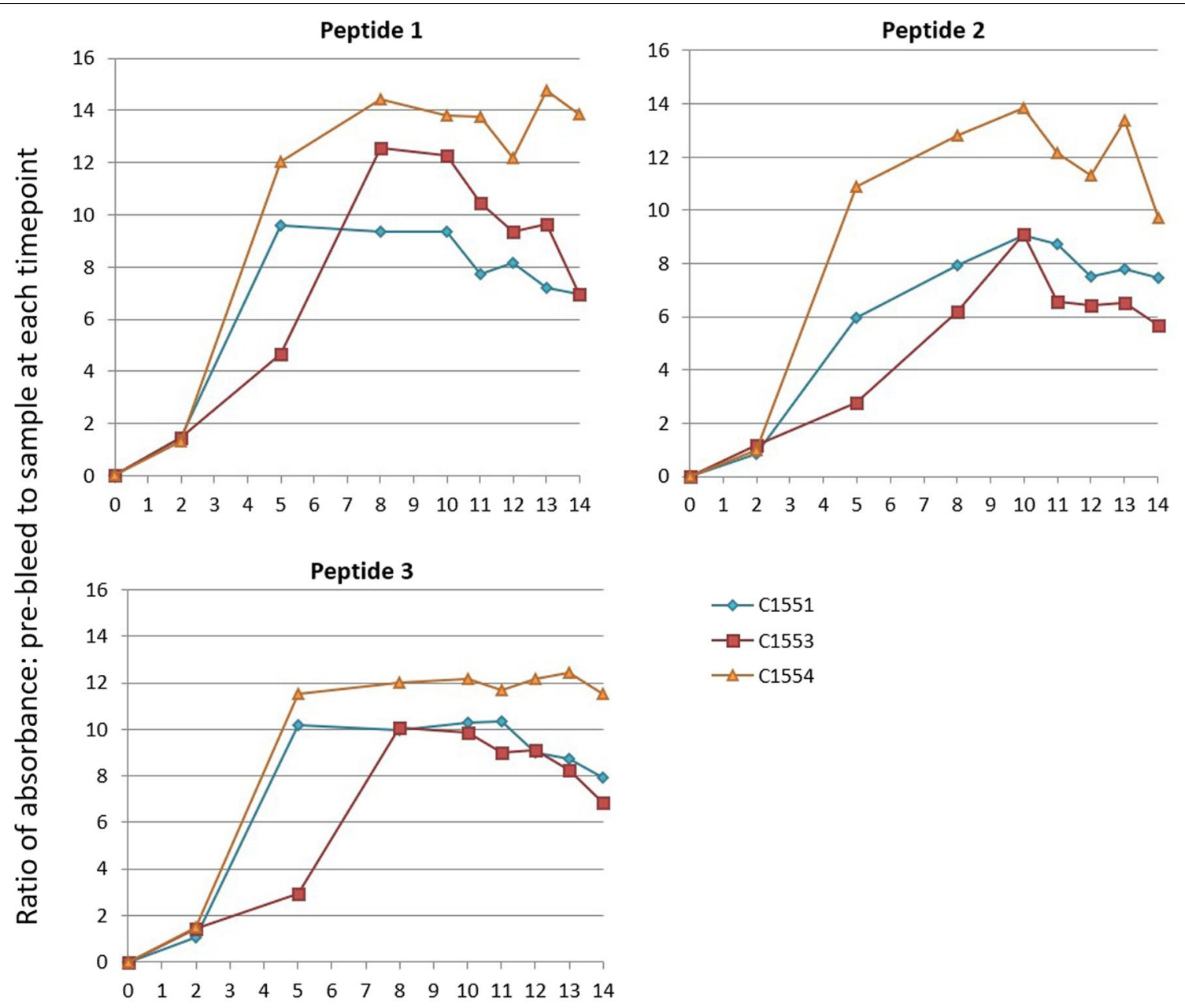

Time: Weeks from fist vaccination

Fig. 2 Antibody titers across the experimental time course. Total lgG response to vaccination for each aquaporin peptide (peptides conjugated to $\mathrm{KLH}$ ). Shown as the ratio of the absorbance at $450 \mathrm{~nm}$ between the pre-bleed sample and the sample at each time point. Sample dilution 1:256. Refer to Fig. 1 for critical experimental time points (last vaccination at week 9, ticks dropping weeks 13-14)

Table 1 Peak titers for each peptide

\begin{tabular}{llll}
\hline & Peptide 1 & Peptide 2 & Peptide 3 \\
\hline $\begin{array}{l}\text { Week of sample } \\
\text { Calf number }\end{array}$ & 8 & 10 & 8 \\
C1551 & 1024 & 1024 & 2048 \\
C1553 & 512 & 512 & 1024 \\
C1554 & 1024 & 1024 & 2048 \\
\hline
\end{tabular}

Lowest dilution of a onefold serial dilution series before loss of reactivity to BSAconjugated peptides in an ELISA

from vaccinated cattle averaged $26.25 \%$ heavier than ticks from the control (Table 4).

Overall, ticks from vaccinated cattle produced a significantly greater weight of eggs than ticks from unvaccinated cattle $(M=0.160 \mathrm{~g}, \quad N=3, \mathrm{SD}=0.002$ vs.
Table 2 Relative amounts of antibody isotypes $\lg G 1$ and lgG2

\begin{tabular}{llllll}
\hline Calf number & Peptide & lgG1 & IgG2 & Total & lgG1/lgG2 \\
\hline C1551 & 1 & 0.630 & 0.349 & 0.979 & 1.81 \\
& 2 & 0.523 & 0.120 & 0.642 & 4.37 \\
& 3 & 0.486 & 0.328 & 0.814 & 1.48 \\
C1553 & 1 & 0.593 & 0.237 & 0.830 & 2.50 \\
& 2 & 0.359 & 0.047 & 0.406 & 7.64 \\
& 3 & 0.448 & 0.215 & 0.663 & 2.08 \\
C1554 & 1 & 1.138 & 0.803 & 1.941 & 1.42 \\
& 2 & 0.637 & 0.191 & 0.828 & 3.33 \\
& 3 & 0.616 & 0.448 & 1.064 & 1.38 \\
\hline
\end{tabular}

Data from samples taken at the highest antibody titer (week 8 for peptides 1 and 3, week 10 for peptide 3). Dilution 1:512, values are absorbance at $450 \mathrm{~nm}$ in ELISA plate reader 


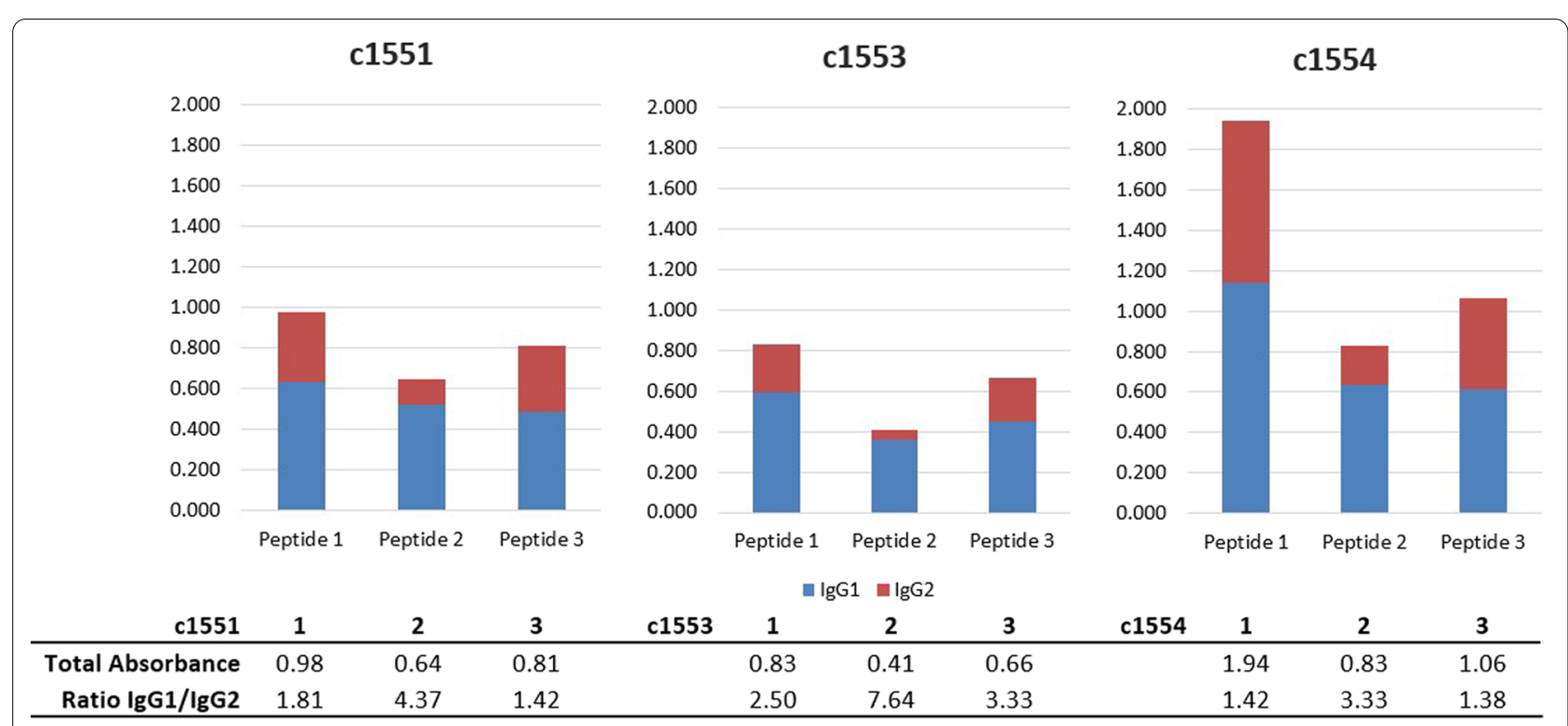

Fig. 3 Antibody isotyping: stacked bar graph showing relative amount (absorbance at $450 \mathrm{~nm}$ ) of $\lg \mathrm{G} 1$ and $\lg \mathrm{g} 2$ for each peptide from each calf. The ratio of absorbance of $\operatorname{lgG} 1 / \operatorname{lgG} 2$ is shown below the graphs for each calf and each peptide

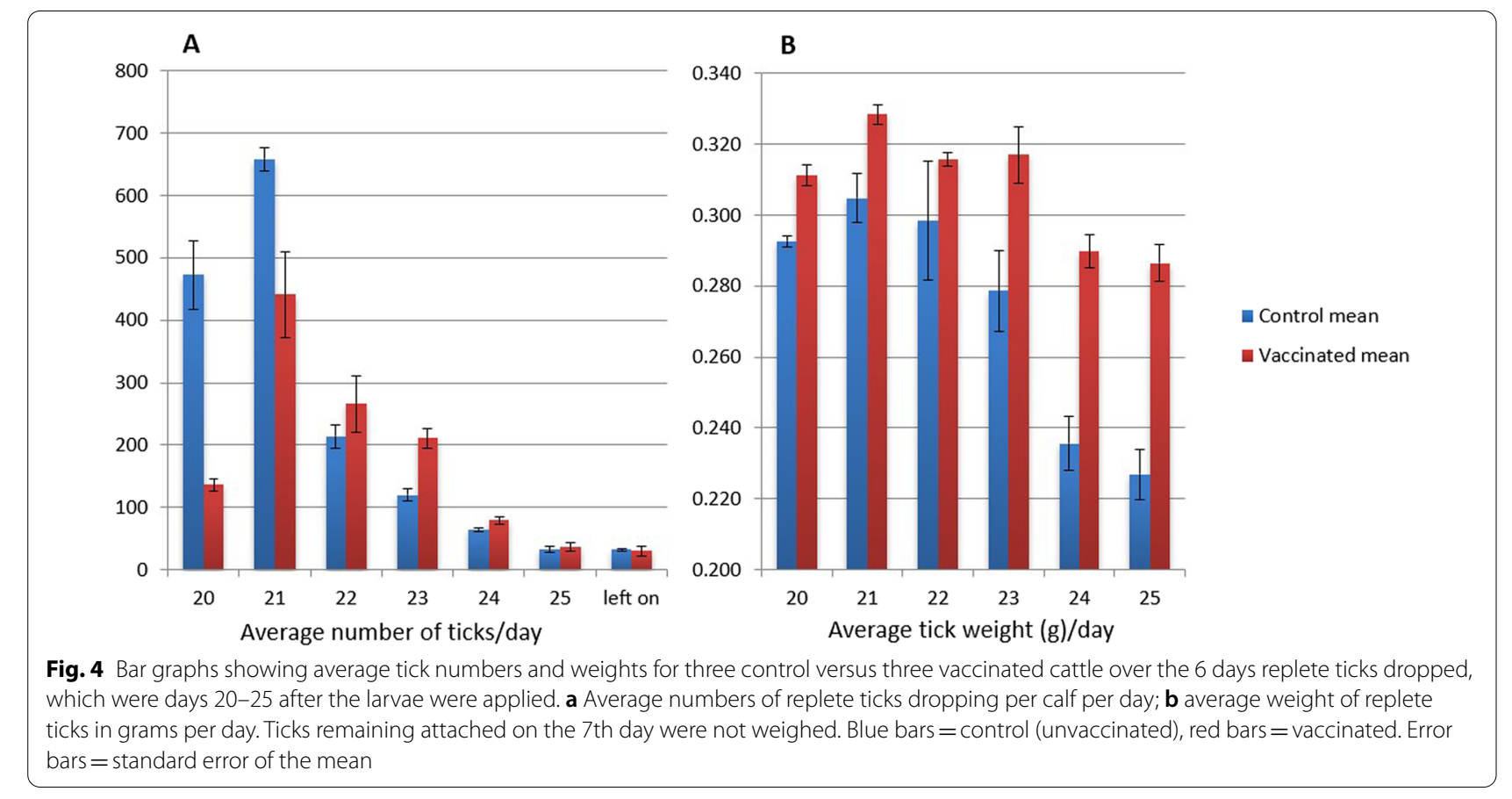

$M=0.136 \mathrm{~g}, N=3, \mathrm{SD}=0.007$, respectively; one-tailed two-sample $t$-test, $d f=4, P=0.0028$ ) (Table 5), and although the difference in conversion ratio was small, the percent of total body mass that was converted to egg mass was higher for ticks from vaccinated cattle than for ticks from unvaccinated cattle, $M=0.517$ (51.7\%), $\mathrm{SD}=0.010$ vs. $M=0.491(49.1 \%), \mathrm{SD}=0.007$, respectively, and the difference was significant at $P=0.05$ (one-tailed twosample $t$-test, $d f=4, P=0.0102$ ), (Table 6). There was no statistical difference in the hatching rate between eggs from vaccinated versus unvaccinated cattle, $M=0.770$ (77.97\%), $\mathrm{SD}=0.009$ vs. $M=0.755$ (75.53\%), $\mathrm{SD}=0.020$, respectively (one-tailed two-sample $t$-test, $P=0.0624$ ) (Table 7), but the hatching rate declined over the course 
Table 3 Total number of ticks collected per calf per day

\begin{tabular}{|c|c|c|c|c|c|c|c|c|}
\hline & \multicolumn{8}{|c|}{ Day of collection } \\
\hline & 20 & 21 & 22 & 23 & 24 & 25 & Left on & Total per calf \\
\hline \multicolumn{9}{|l|}{ Control } \\
\hline C1557 & 506 & 620 & 200 & 103 & 71 & 32 & 32 & 1564 \\
\hline C1559 & 364 & 672 & 251 & 136 & 61 & 40 & 29 & 1553 \\
\hline C1560 & 546 & 682 & 190 & 121 & 63 & 26 & 36 & 1664 \\
\hline Daily mean & 472 & 658 & 214 & 120 & 65 & 33 & 32 & 1594 \\
\hline SD & 95.65 & 33.29 & 32.72 & 16.52 & 5.29 & 7.02 & 3.51 & 61.16 \\
\hline SEM & 55.22 & 19.22 & 18.89 & 9.54 & 3.06 & 4.06 & 2.03 & 35.31 \\
\hline \multicolumn{9}{|l|}{ Vaccinated } \\
\hline C1551 & 130 & 574 & 348 & 228 & 74 & 39 & 32 & 1425 \\
\hline C1553 & 124 & 346 & 260 & 179 & 92 & 25 & 16 & 1042 \\
\hline C1554 & 156 & 403 & 190 & 225 & 72 & 46 & 43 & 1135 \\
\hline Daily mean & 137 & 441 & 266 & 211 & 79 & 37 & 30 & 1201 \\
\hline SD & 17.01 & 118.65 & 79.17 & 27.47 & 11.02 & 10.69 & 13.58 & 199.77 \\
\hline SEM & 9.82 & 68.51 & 45.71 & 15.86 & 6.36 & 6.17 & 7.84 & 115.33 \\
\hline
\end{tabular}

Day of collection $=$ number of days since larval ticks were first applied. SD standard deviation, SEM standard error of the mean

Table 4 Average weight of ticks collected from each calf each day

\begin{tabular}{|c|c|c|c|c|c|c|c|c|c|c|c|c|c|}
\hline & \multicolumn{13}{|c|}{ Day of collection } \\
\hline & \multicolumn{2}{|l|}{20} & \multicolumn{2}{|l|}{21} & \multicolumn{2}{|l|}{22} & \multicolumn{2}{|l|}{23} & \multicolumn{2}{|l|}{24} & \multicolumn{2}{|l|}{25} & \multirow[t]{2}{*}{ Mean per calf } \\
\hline & wt & $n$ & wt & $n$ & wt & $n$ & wt & $n$ & wt & $n$ & wt & $n$ & \\
\hline \multicolumn{14}{|l|}{ Control } \\
\hline C1557 & 0.292 & 72 & 0.294 & 72 & 0.278 & 72 & 0.260 & 72 & 0.230 & 59 & 0.213 & 22 & 0.269 \\
\hline C1559 & 0.291 & 72 & 0.318 & 72 & 0.332 & 72 & 0.299 & 72 & 0.251 & 51 & 0.237 & 29 & 0.296 \\
\hline C1560 & 0.295 & 72 & 0.303 & 72 & 0.285 & 72 & 0.276 & 72 & 0.226 & 53 & 0.231 & 16 & 0.278 \\
\hline Daily mean & 0.293 & & 0.305 & & 0.298 & & 0.279 & & 0.236 & & 0.227 & & 0.281 \\
\hline SD & 0.0024 & & 0.0121 & & 0.0292 & & 0.0198 & & 0.0130 & & 0.0125 & & 0.014 \\
\hline SEM & 0.0014 & & 0.0070 & & 0.0168 & & 0.0114 & & 0.0075 & & 0.0072 & & 0.008 \\
\hline \multicolumn{14}{|l|}{ Vaccinated } \\
\hline C1551 & 0.312 & 72 & 0.325 & 72 & 0.3150 & 72 & 0.312 & 72 & 0.283 & 62 & 0.293 & 29 & 0.309 \\
\hline C1553 & 0.306 & 72 & 0.326 & 72 & 0.3128 & 72 & 0.307 & 72 & 0.288 & 71 & 0.290 & 15 & 0.307 \\
\hline C1554 & 0.316 & 72 & 0.334 & 72 & 0.3190 & 72 & 0.332 & 72 & 0.298 & 62 & 0.276 & 35 & 0.316 \\
\hline Daily mean & 0.311 & & 0.328 & & 0.3156 & & 0.317 & & 0.290 & & 0.286 & & 0.311 \\
\hline SD & 0.0049 & & 0.0050 & & 0.0031 & & 0.0135 & & 0.0079 & & 0.0088 & & 0.0050 \\
\hline SEM & 0.0028 & & 0.0029 & & 0.0018 & & 0.0078 & & 0.0046 & & 0.0051 & & 0.0029 \\
\hline
\end{tabular}

$\mathrm{wt}=$ Average weight in grams for $n$ ticks collected on each day. Day of collection $=$ number of days since larval ticks were first applied. $n=$ number of ticks include in the average for the day. SD standard deviation. SEM standard error of the mean

of tick drop, from $78.0 \%$ to $66.9 \%$ for ticks from control cattle and from 84.0 to $67.7 \%$ for vaccinated cattle (Fig. 5).

\section{Protein content of replete female ticks}

Overall, there was no statistically significant difference in the protein content of ticks (measured as soluble protein as a proportion of total tick weight) from vaccinated versus control cattle, $M=0.256(25.6 \%), \mathrm{SD}=0.017$ vs.
$M=0.244(24.4 \%), \mathrm{SD}=0.006$, respectively (one-tailed two-sample $t$-test, $d f=4, P=0.1538$ ) (Table 8 and Additional file 5: Data file S5).

\section{Discussion}

We have demonstrated that vaccination of cattle with synthetic peptides corresponding to the predicted extracellular domains of the RmAQP2 protein can produce an immune response that leads to a reduction in the number 
Table 5 Average weight of individual egg masses for a sample of $n$ egg masses per day per calf

\begin{tabular}{|c|c|c|c|c|c|c|c|c|c|c|c|c|c|}
\hline & \multicolumn{11}{|c|}{ Day of collection } & & \multirow{3}{*}{ Mean per calf } \\
\hline & \multicolumn{2}{|l|}{20} & \multicolumn{2}{|l|}{21} & \multicolumn{2}{|l|}{22} & \multicolumn{2}{|l|}{23} & \multicolumn{2}{|l|}{24} & \multicolumn{2}{|l|}{25} & \\
\hline & wt & $n$ & wt & $n$ & wt & $n$ & wt & $n$ & wt & $n$ & wt & $n$ & \\
\hline \multicolumn{14}{|l|}{ Control } \\
\hline C1557 & 0.146 & 69 & 0.150 & 69 & 0.131 & 67 & 0.136 & 65 & 0.116 & 53 & 0.100 & 22 & 0.130 \\
\hline C1559 & 0.152 & 70 & 0.158 & 71 & 0.161 & 45 & 0.149 & 66 & 0.121 & 45 & 0.125 & 25 & 0.144 \\
\hline C1560 & 0.157 & 71 & 0.159 & 69 & 0.145 & 67 & 0.122 & 68 & 0.112 & 49 & 0.109 & 11 & 0.134 \\
\hline Daily mean & 0.152 & & 0.156 & & 0.146 & & 0.136 & & 0.116 & & 0.111 & & 0.136 \\
\hline $\mathrm{SD}$ & 0.0051 & & 0.0049 & & 0.0151 & & 0.0134 & & 0.0048 & & 0.0124 & & 0.007 \\
\hline SEM & 0.0030 & & 0.0028 & & 0.0087 & & 0.0077 & & 0.0028 & & 0.0071 & & 0.004 \\
\hline \multicolumn{14}{|l|}{ Vaccinated } \\
\hline C1551 & 0.159 & 67 & 0.168 & 70 & 0.163 & 68 & 0.160 & 70 & 0.154 & 54 & 0.154 & 24 & 0.160 \\
\hline C1553 & 0.163 & 71 & 0.175 & 70 & 0.168 & 71 & 0.166 & 72 & 0.151 & 67 & 0.145 & 15 & 0.161 \\
\hline C1554 & 0.166 & 69 & 0.168 & 68 & 0.160 & 68 & 0.168 & 67 & 0.146 & 59 & 0.141 & 25 & 0.158 \\
\hline Daily mean & 0.163 & & 0.171 & & 0.164 & & 0.165 & & 0.150 & & 0.147 & & 0.160 \\
\hline SD & 0.0037 & & 0.0040 & & 0.0040 & & 0.0042 & & 0.0041 & & 0.0067 & & 0.0016 \\
\hline SEM & 0.0021 & & 0.0023 & & 0.0023 & & 0.0024 & & 0.0024 & & 0.0039 & & 0.0009 \\
\hline
\end{tabular}

$\mathrm{wt}=$ Average weight in grams for $n$ egg masses from ticks collected on each day. Day of collection $=$ number of days since larval ticks were first applied. $n=$ number of ticks include in the average for the day. SD standard deviation, SEM standard error of the mean

Table 6 Conversion rate: average proportion of total body weight converted to eggs for ticks from each calf on each day

\begin{tabular}{|c|c|c|c|c|c|c|c|c|c|c|c|c|c|}
\hline & \multicolumn{11}{|c|}{ Date of collection } & & \multirow[t]{3}{*}{ Mean conversion } \\
\hline & \multicolumn{2}{|l|}{20} & \multicolumn{2}{|l|}{21} & \multicolumn{2}{|l|}{22} & \multicolumn{2}{|l|}{23} & \multicolumn{2}{|l|}{24} & \multicolumn{2}{|l|}{25} & \\
\hline & Rate & $n$ & Rate & $n$ & Rate & $\mathrm{n}$ & Rate & $\mathrm{n}$ & Rate & $n$ & Rate & $n$ & \\
\hline \multicolumn{14}{|l|}{ Control } \\
\hline C1557 & 0.499 & 69 & 0.511 & 69 & 0.472 & 67 & 0.515 & 65 & 0.474 & 51 & 0.454 & 22 & 0.488 \\
\hline C1559 & 0.519 & 72 & 0.496 & 72 & 0.493 & 72 & 0.501 & 72 & 0.473 & 51 & 0.509 & 29 & 0.499 \\
\hline C1560 & 0.529 & 72 & 0.525 & 72 & 0.507 & 72 & 0.432 & 72 & 0.477 & 53 & 0.447 & 16 & 0.486 \\
\hline Daily mean & 0.516 & & 0.511 & & 0.491 & & 0.483 & & 0.475 & & 0.470 & & 0.491 \\
\hline $\mathrm{SD}$ & 0.0153 & & 0.0145 & & 0.0176 & & 0.0444 & & 0.0021 & & 0.034 & & 0.007 \\
\hline SEM & 0.0088 & & 0.0084 & & 0.0102 & & 0.0257 & & 0.0012 & & 0.0196 & & 0.004 \\
\hline \multicolumn{14}{|l|}{ Vaccinated } \\
\hline C1551 & 0.507 & 72 & 0.518 & 72 & 0.517 & 72 & 0.518 & 72 & 0.512 & 62 & 0.522 & 29 & 0.516 \\
\hline C1553 & 0.536 & 72 & 0.540 & 72 & 0.534 & 72 & 0.549 & 72 & 0.506 & 71 & 0.501 & 15 & 0.528 \\
\hline C1554 & 0.529 & 69 & 0.507 & 68 & 0.508 & 68 & 0.506 & 67 & 0.489 & 59 & 0.506 & 25 & 0.508 \\
\hline Daily mean & 0.524 & & 0.522 & & 0.520 & & 0.524 & & 0.503 & & 0.501 & & 0.517 \\
\hline SD & 0.0149 & & 0.0170 & & 0.0134 & & 0.0220 & & 0.0118 & & 0.0108 & & 0.0102 \\
\hline SEM & 0.0086 & & 0.0098 & & 0.0077 & & 0.0127 & & 0.0068 & & 0.0062 & & 0.0059 \\
\hline
\end{tabular}

Average proportion of total body weight converted to eggs for a sample of $n$ ticks collected from each calf each day. Day of collection $=$ number of days since larval ticks were first applied. $n=$ number of ticks include in the average for the day. SD standard deviation, SEM standard error of the mean

of ticks successfully feeding to repletion when cattle are challenged with $R$. microplus larvae. There was an overall average of $25 \%$ fewer replete female ticks on the vaccinated cattle, all three vaccinated cattle produced fewer ticks than any of the control cattle, but there was substantial variation, and two of the vaccinated cattle (C1553, C1554) performed much better than the third (C1551).
Animal health evaluations over the course of the experiment indicated that C1551 suffered from a "failure to thrive" and had slower weight gain than the other cattle, which might explain why this calf was less well protected by vaccination. If we exclude $\mathrm{C} 1551$ from the evaluation, there was an overall $32 \%$ reduction in ticks produced comparing the three control animals with vaccinated 
Table 7 Average percent of eggs hatching for a sample of $n$ ticks per day per calf

\begin{tabular}{|c|c|c|c|c|c|c|c|c|c|c|c|c|c|}
\hline & \multicolumn{13}{|c|}{ Day of collection } \\
\hline & \multicolumn{2}{|l|}{20} & \multicolumn{2}{|l|}{21} & \multicolumn{2}{|l|}{22} & \multicolumn{2}{|l|}{23} & \multicolumn{2}{|l|}{24} & \multicolumn{2}{|l|}{25} & \multirow[t]{2}{*}{ Mean \% per calf } \\
\hline & $\%$ & $n$ & $\%$ & $n$ & $\%$ & $n$ & $\%$ & $n$ & $\%$ & $n$ & $\%$ & $n$ & \\
\hline \multicolumn{14}{|l|}{ Control } \\
\hline C1557 & 75.25 & 47 & 83.50 & 47 & 75.06 & 46 & 83.09 & 48 & 77.39 & 48 & 71.88 & 22 & 77.70 \\
\hline C1559 & 78.77 & 48 & 77.16 & 48 & 78.75 & 43 & 68.15 & 44 & 76.43 & 46 & 63.63 & 17 & 73.82 \\
\hline C1560 & 80.01 & 48 & 79.17 & 45 & 81.24 & 46 & 75.19 & 46 & 69.77 & 47 & 65.06 & 11 & 75.07 \\
\hline Daily mean & 78.01 & & 79.94 & & 78.35 & & 75.48 & & 74.53 & & 66.86 & & 75.53 \\
\hline $\mathrm{SD}$ & 2.46 & & 3.24 & & 3.11 & & 7.47 & & 4.15 & & 4.41 & & 1.98 \\
\hline SEM & 1.42 & & 1.87 & & 1.79 & & 4.31 & & 2.40 & & 2.55 & & 1.14 \\
\hline \multicolumn{14}{|l|}{ Vaccinated } \\
\hline C1551 & 81.72 & 47 & 72.36 & 47 & 83.20 & 47 & 80 & 47 & 78.13 & 46 & 74.77 & 24 & 78.44 \\
\hline C1553 & 88.29 & 47 & 78.31 & 48 & 83.30 & 48 & 87.92 & 42 & 75.90 & 43 & 57.55 & 15 & 78.55 \\
\hline C1554 & 84.8 & 46 & 81.46 & 47 & 78.39 & 47 & 79.70 & 48 & 66.20 & 48 & 70.90 & 24 & 76.92 \\
\hline Daily mean & 84.95 & & 77.38 & & 81.63 & & 82.69 & & 73.41 & & 67.74 & & 77.97 \\
\hline SD & 3.29 & & 4.62 & & 2.81 & & 4.54 & & 6.34 & & 9.04 & & 0.91 \\
\hline SEM & 1.90 & & 2.67 & & 1.62 & & 2.62 & & 3.66 & & 5.22 & & 0.53 \\
\hline
\end{tabular}

$\%=$ Average percent of a subsample of eggs hatching for a sample of $n$ egg masses per day per calf. Day of collection $=$ number of days since larval ticks were first applied. $n=$ number of egg masses sampled for the calf on the day. SD standard deviation, SEM standard error of the mean

Table 8 Average total soluble protein per gram of tick

\begin{tabular}{|c|c|c|c|c|c|c|c|}
\hline & \multicolumn{6}{|c|}{ Day of collection } & \multirow[t]{2}{*}{ Mean per calf } \\
\hline & 20 & 21 & 22 & 23 & 24 & 25 & \\
\hline \multicolumn{8}{|l|}{ Control } \\
\hline C1557 & 0.247 & 0.249 & 0.245 & 0.261 & 0.232 & 0.196 & 0.238 \\
\hline C1559 & 0.252 & 0.249 & 0.244 & 0.273 & 0.218 & 0.222 & 0.243 \\
\hline C1560 & 0.245 & 0.261 & 0.271 & 0.253 & 0.236 & 0.232 & 0.250 \\
\hline Daily mean & 0.248 & 0.253 & 0.253 & 0.262 & 0.229 & 0.217 & 0.244 \\
\hline SD & 0.0036 & 0.0069 & 0.0153 & 0.0101 & 0.0095 & 0.0186 & 0.006 \\
\hline SEM & 0.0021 & 0.0040 & 0.0088 & 0.0058 & 0.0055 & 0.0107 & 0.003 \\
\hline \multicolumn{8}{|l|}{ Vaccinated } \\
\hline C1551 & 0.241 & 0.233 & 0.278 & 0.279 & 0.223 & 0.202 & 0.243 \\
\hline C1553 & 0.249 & 0.249 & 0.291 & 0.341 & 0.244 & 0.277 & 0.275 \\
\hline C1554 & 0.232 & 0.248 & 0.323 & 0.272 & 0.235 & 0.185 & 0.249 \\
\hline Daily mean & 0.241 & 0.243 & 0.297 & 0.297 & 0.234 & 0.221 & 0.256 \\
\hline SD & 0.0085 & 0.0090 & 0.0232 & 0.0380 & 0.0105 & 0.0490 & 0.017 \\
\hline SEM & 0.0049 & 0.0052 & 0.0134 & 0.0219 & 0.0061 & 0.0283 & 0.010 \\
\hline
\end{tabular}

Day of collection $=$ number of days since larval ticks were first applied, each value $=$ the average protein content per gram of tick for a random sample of 10 replete ticks per calf per day

animals $\mathrm{C} 1553$ and $\mathrm{C} 1554$ alone. However, by all other measures, C1551 performed similarly to the other cattle, and for all further evaluations this calf was considered to be equivalent to the other animals.

Although previously published results from our lab suggested that expression of aquaporin was greatest in the salivary glands [22], a detailed re-examination of the tissue-specific expression of aquaporin 2 at different tick life stages (data not shown) suggested that this gene may be upregulated to a greater extent in the ovary than in the salivary glands. Consequently, we used protein isolated from tick ovaries in protein immunoblots (western blots) to confirm an immune response to native protein. Polyclonal immune sera from vaccinated cattle bound to 
$\mathrm{a} \approx 50-55 \mathrm{KDa}$ tick ovary protein band on western blots; the same band was absent from either pre-vaccination serum or serum from control animals. These results recapitulate what was seen in the previously published work [22], although using a peptide 2-specific monoclonal antibody binding to native tick gut protein in the previous work allowed bands to be seen much more clearly than we were able to see working with polyclonal serum from vaccinated animals and binding to native ovary protein. Even though clear banding patterns were much more difficult to visualize, the 50-55 KDa band was definitively seen only in vaccinated animals.

Vaccination with synthetic peptides that had been conjugated to KLH and adjuvanted with saponin produced an immune response that was sufficient to impact tick feeding success. For peptides 1 and 3 vaccinated cattle reached the peak of their immune response after the third vaccination with conjugated peptide, the final boost with unconjugated peptides had very little impact on peak titer. In the case peptide 2 , all three calves reached their peak titers at week 10, 1 week after the peptide boost. Peptide 1 provided the highest level of response, and there was a similar pattern of response to all peptides across the three vaccinated calves (Figs. 2 and 3). With regard to the overall magnitude of the response, all three cattle responded differently, but consistently, with C1554 achieving the maximum total IgG titers, C1551 intermediate, and C1553 the lowest response. The larval ticks were applied on day 70, 1 week after the final peptide boost at day 63; since titers peaked at 8 weeks (56 days) for peptides 1 and 3 and 10 weeks (70 days) for peptide 2 , the larval ticks were first beginning to attach and feed after the highest titers were achieved, and by the time the adults began feeding (20 days after larval ticks were applied) at approximately 85 days after the first vaccination, titers to all three peptides were beginning to drop. Although we could not quantify tick numbers before adult repletion, there appeared to be fewer ticks on the vaccinated animals when we visually inspected the larval ticks in the feeding patch at day 5 and the early nymphal ticks at day 9, suggesting that the survival of larval and nymphal ticks, which were exposed to higher antibody titers than the adults, may have been impacted by vaccination. Days 5 and 9 were chosen for these observations because these time points bracket the time larval ticks would be transitioning to the nymphal stage, a critical point in the development of this one-host tick. We suggest that if the timing of the tick feeding had corresponded better with the peak antibody titers, vaccination may have had a greater impact on the tick survival. As it was, none of the tick life stages, including the adult ticks in particular, which take the largest amount of blood (and thus are exposed to the greatest amount of antibody), were exposed to peak antibody titers. We hypothesize that if we had placed the ticks on the cattle sooner, or continued vaccination longer, they would have been exposed to higher antibody levels, which may have resulted in greater tick mortality. If this is the case, however, in order for these peptides to be an effective vaccine, methods will need to be developed to produce sustained high antibody levels.

The vaccinated calf with the highest overall anti-peptide antibody titers, C1554, produced an intermediate number of replete female ticks compared to the numbers on the other vaccinated calves, which had lower antibody titers, suggesting that there is no direct relationship between titer and vaccine efficacy. Isotyping data showed that $\mathrm{C} 1554$ had high levels of both IgG1 and IgG2 but the lowest ratios of IgG1 to IgG2. Ticks were best controlled (fewest replete females) on $\mathrm{C} 1553$, which had the lowest overall levels of total IgG antibody but had the highest IgG1/IgG2 ratios, whereas C1551, which had the highest tick burden, had intermediate levels of total IgG and also intermediate IgG1/IgG2 ratios (Table 2). IgG1 and IgG2 are the dominant antibody isotypes in cattle, and each has its own functional phenotype [28]. IgG1 fixes complement [29] and is overwhelmingly preferentially secreted in colostrum [28, 30,31], whereas IgG2 may be less involved in complement fixation than IgG1 [28, 29] and may be more involved in opsonization [28]. A previous anti-tick vaccine study suggested that levels of IgG1 were correlated with the levels of protection when cattle were vaccinated with tick midgut proteins [32], although that does not appear to be the case in this study. Perhaps because of its role as a secreted component of colostrum [31], IgG1 has become adapted to be functionally more stable outside of the circulatory milieu, and this may make it better able to bind exposed tick aquaporin epitopes once it has passed into the gut of the tick. On the other hand, IgG1 and IgG2 have different sensitivities to proteolysis - for example, in a mixture of IgG1 and IgG2, pepsin will cleave all IgG1 and leave IgG2 intact [28] - and it has been suggested that the protein degradation machinery of the tick might play a role in anti-tick vaccine efficacy [33]. Conceivably, antibody isotypes that are less susceptible to proteolytic degradation might play a more important role in binding to targets in the tick. If IgG2 is involved in opsonization, binding to targets within the tick may promote the activity of the tick innate immune response by activating phagocytic hemocytes. All three vaccinated cattle had high levels of IgG1 but greatly differing levels of IgG2. Levels of IgG2 were lowest in C1551 and C1553, where tick control was the most effective, suggesting that the overall effect is a result of interplay between the isotypes rather than absolute levels of one or the other. Although more 
data are needed to draw any definitive conclusions, we hypothesize that immune responses that can be directed towards higher IgG1/IgG2 ratios may be more effective. Although Holstein cattle are relatively homogeneous genetically, individual animals will still respond differently to immune stimuli based on their unique immunogenetic backgrounds. It may be that the choice of specific epitopes themselves, or the choice of conjugate or adjuvant, could play some role in directing the antibody isotype responses. It is clear from these data (Figs. 2 and 3, Table 2) that different peptide sequences can stimulate different levels and types of immune responses.

The only treatment difference between control cattle and vaccinated cattle was the presence of the peptides conjugated to the KLH; control cattle were injected with adjuvant and KLH alone (without conjugated peptides). Consequently, any effect on tick survival and feeding success must be related to the immune response to the conjugated peptides and not a result of general upregulation of innate immunity caused by immune stimulation by KLH. KLH has been used previously in anti-tick vaccine research [34] and in other types of vaccine research and development for enhancing immune response to conjugated peptides $[35,36]$, and although it is highly antigenic, there is little information about how an immune response specific to KLH might impact innate immunity.

The fully fed female ticks dropping from all vaccinated cattle had significantly greater replete weights on average than the controls, which recapitulates the results from the RNA silencing experiments that had previously been performed [22]. We had hypothesized that when the function of RmAQP2 is abrogated, either by RNAi or by binding of immune proteins, ticks may be less able to remove excess water from the blood meal, possibly resulting in reduced levels of protein acquisition and consequent reduced egg production. We tested this hypothesis in two ways, with a protein assay to determine whether the level of soluble protein as a proportion of total tick weight was different in ticks fed on vaccinated versus unvaccinated cattle, and by weighing eggs and calculating the efficiency of conversion of total body weight into weight of eggs. In either case, if the tick weight was

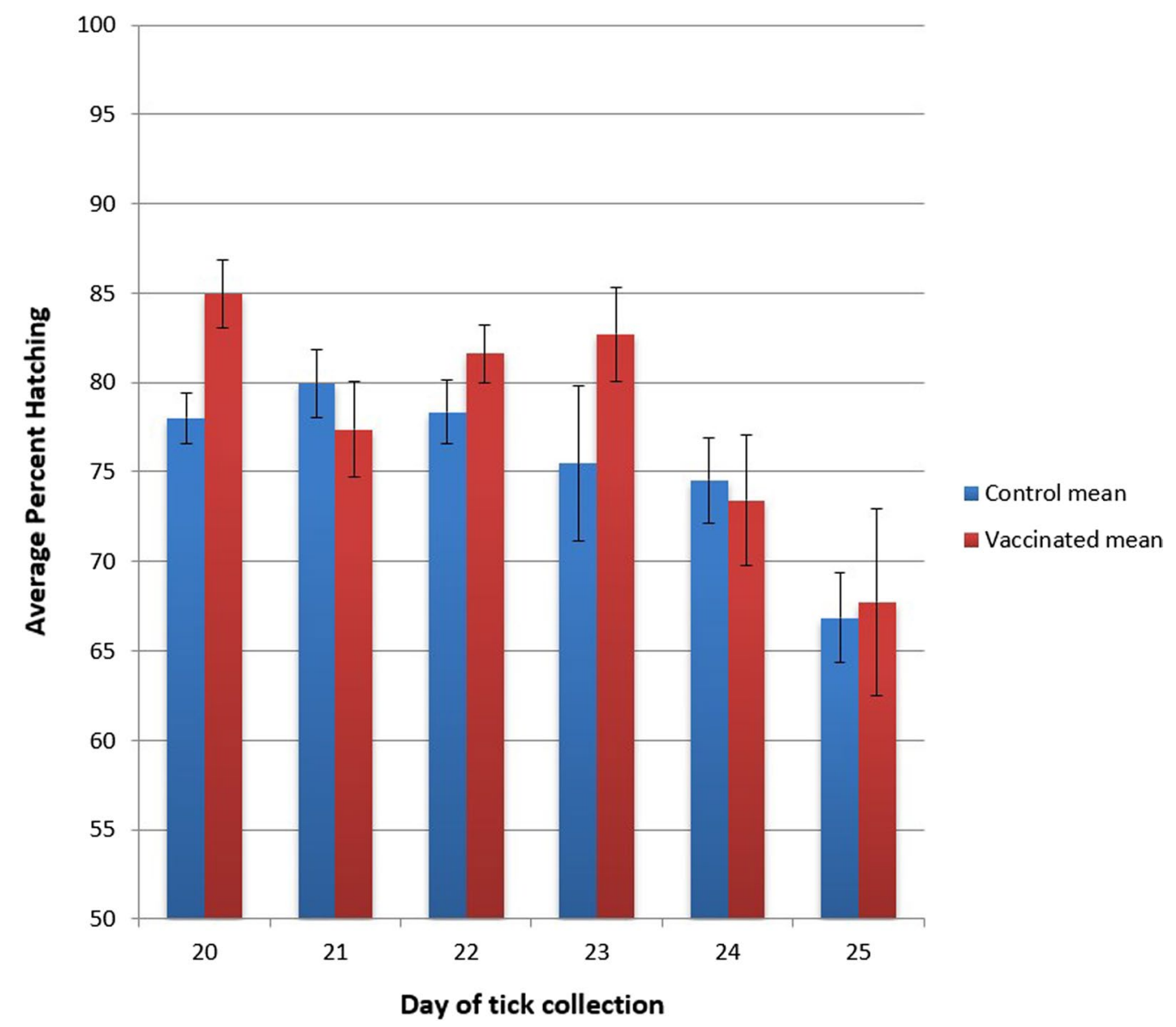

Fig. 5 Daily egg hatching rate over 6 days ticks were dropping, which were days 20-25 after the larvae were applied. Average \% hatching of a subsample of eggs from 48 egg masses from each calf on each day. Error bars=standard error of the mean. Blue bars=control (unvaccinated), red bars $=$ vaccinated 
greater because excess water was not removed, either the proportion of total body weight converted to eggs or proportion of the total weight made up of soluble protein should be lower for the ticks fed on vaccinated versus control animals, but there was no statistically significant difference overall in either conversion or protein content between ticks fed on vaccinated versus unvaccinated cattle. We conclude that the difference in weight of the blood meals is not related to water content and that the vaccinated ticks were taking larger blood meals.

Interestingly, the difference in weight between ticks fed on vaccinated versus unvaccinated cattle increased with the time it took to feed, with the greatest difference seen in ticks that dropped on the last day (26.25\%) as compared to those that dropped on the first day $(6.36 \%)$, suggesting that the longer the ticks were exposed to the antibody, the greater the effect. Our hypothesis that the differences in replete weight were the result of the inability to remove water from the blood meal was not supported. Since the ticks on vaccinated cattle took longer to feed, the difference in replete weight may be related to feeding time; however, it is unknown how vaccination may influence feeding time. Although we are left with no hypothetical mechanism, it is clear that vaccination has a similar effect to that seen with RNA silencing of aquaporin 2 [22]. Further investigation will be needed to understand the basis of this effect.

Studies on the effect of vaccination on the hatching rate of eggs produced by ticks fed on vaccinated versus control animals confirm that hatching was not impacted by vaccination: the hatching rate was the same for eggs laid by females fed on vaccinated or unvaccinated cattle. Unfortunately, since we weighed total egg production of each female but did not count the number of eggs produced, we cannot draw any conclusion relating to reproductive success of individual female ticks. However, in light of the $25 \%$ reduction in the total number of replete females produced, the reproductive success of the population as a whole would have been negatively impacted in the vaccinated group due to the presence of fewer ovipositing females.

Overall, these data suggest that RmAQP2 could be a useful component of an anti-tick vaccine cocktail consisting of multiple targets. Although $25 \%$ reduction in the number of replete ticks is significant, it would not be enough by itself to reduce the need to acaricides. It may be necessary to combine several targets to increase the effectiveness of an anti-tick vaccine to levels that will provide sufficient control to do away with the need for acaricide treatment. Multiple targets combined into a single vaccine may also reduce the likelihood that tick populations might adapt and escape control [37, 38]. Most importantly, this work suggests that a full-length expressed protein is not required to induce a protective immune response. Targeting extracellular peptide domains is sufficient to produce an immune response that can interfere with Aquaporin function, resulting in reduced tick survival overall. However, conjugation of peptides to an antigenic carrier such as KLH is critical as we saw that vaccination with peptides alone did not boost titers, even after 3 vaccinations with conjugated peptides. The ability to use peptide domains as vaccine targets may make it easier to include multiple targets to create multivalent vaccines.

There are ongoing research efforts to identify more consistently effective anti-tick vaccine targets; however, there has been little research towards developing methods for maintaining effectively high antibody levels. Since tick gut proteins like the aquaporins are concealed antigens (as are Bm86 and its various orthologs), there is no natural boost from exposure to tick feeding, and consequently methods are needed to maintain high antibody levels in order to get adequate protection without the need for periodic revaccination. Revaccination of animals on a regular basis (as is called for with the Bm86-based vaccines) is expensive and ultimately unsustainable. In order to use anti-tick vaccination approaches targeting concealed antigens in the most effective way, it will be important to explore new methods for expression of antigens to constantly boost antibody production and maintain antibody titers, such as transfection into attenuated persistently infecting pathogen strains, as has been suggested for Babesia bovis $[39,40]$.

\section{Conclusions}

Vaccination resulted in a $25 \%$ reduction in the number of ticks feeding to repletion. Although this is not sufficient to eliminate the need for acaricides, it does suggest that RmAQP2 could be a useful component of an anti-tick vaccine cocktail which includes other antigens. Further, we have shown here that peptide vaccination can be an effective tool for testing antigens, bypassing the need for expression of full-length protein targets.

\footnotetext{
Abbreviations

Bm86: Boophilus microplus antigen 86; BSA: Bovine serum albumin; $d f$ : Degrees of freedom; DMSO: Dimethyl sulfoxide; ELISA: Enzyme-linked immunosorbent assay; IgG: Immunoglobulin G; IgG1: Immunoglobulin G subclass 1; IgG2: Immunoglobulin G subclass 2; KDa: Kilodaltons; KLH: Keyhole limpet hemocyanin; M: Mean; PBS: Phosphate-buffered saline; RmAQP2: R. microplus aquaporin 2; SD: Standard deviation.
} 


\section{Supplementary Information}

The online version contains supplementary material available at https://doi. org/10.1186/s13071-022-05166-1.

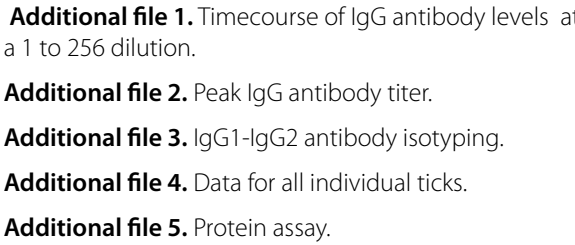

Additional file 1. Timecourse of lgG antibody levels at a 1 to 256 dilution

Additional file 2. Peak lgG antibody titer

Additional file 3. $\lg$ G1-lgG2 antibody isotyping

Additional file 4. Data for all individual ticks.

Additional file 5. Protein assay.

\section{Acknowledgements}

Cecily Parell performed the analysis of AQP2 expression mentioned in this paper as data not shown. We thank James Allison and Megan Jacks for animal care and handling, and Gavin Scoles for assistance with tick work.

\section{Authors' contributions}

GAS conceived the study, supervised its completion, analyzed the data, and wrote the paper. HEH and CLO participated in experimental design, provided technical assistance, and edited the manuscript. KLM provided technical support with all aspects of the tick work, data collection, tabulation, and analysis. SD designed and carried out all of the immunological assays, assisted in data collection, tabulation, and analysis, and writing of the methods. KLM and SD revised and reviewed drafts of the manuscript. All authors read and approved the final manuscript.

\section{Author's information}

This work was carried out at the USDA-ARS Animal Disease Research Unit farm facility at the University of Idaho, Moscow, ID, prior to the transfer of GAS to the ARS lab in Beltsville, MD. GAS is a Research Entomologist for the USDAAgricultural Research Service. HEH is on the faculty of the University of Cairo, Egypt, and has an Associate Research Faculty appointment at Washington State University. CLO was a Postdoctoral Associate at the University of Idaho when this work was completed but has since taken a position as Assistant Professor at Kansas State University. SD is a Biological Science Research Technician, and KLM is a Support Scientist at the Animal Disease Research Unit in Pullman, WA.

\section{Funding}

This work was funded by USDA, ARS CRIS project \# 2090-32000-039-000-D.

\section{Availability of data and materials}

All relevant raw data used to support the conclusions of this study have been included as additional data files or are available from the corresponding author.

\section{Declarations}

Ethics approval and consent to participate

All animal use was approved by the University of Idaho Institutional Animal Care and Use Committee (IACUC), protocol \#2016-27.

\section{Consent for publication}

Not applicable.

\section{Competing interests}

The authors declare that they have no competing interests.

\section{Author details}

${ }^{1}$ USDA-ARS, Animal Disease Research Unit, Washington State University, Pullman, WA, USA. ${ }^{2}$ Department of Veterinary Microbiology and Pathology, Washington State University, Pullman, WA, USA. ${ }^{3}$ Department of Entomology, Faculty of Science, Cairo University, Giza, Egypt. ${ }^{4}$ Department of Entomology, Plant Pathology and Nematology, University of Idaho, Moscow, ID, USA. ${ }^{5}$ Present Address: USDA-ARS, Invasive Insect Biocontrol and Behavior Lab,
Beltsville Agricultural Research Center, Beltsville, MD, USA. ${ }^{6}$ Present Address: Department of Entomology, Kansas State University, Manhattan, KS, USA.

Received: 28 September 2021 Accepted: 17 January 2022

Published online: 08 February 2022

\section{References}

1. de la Fuente J, Estrada-Pena A, Venzal JM, Kocan KM, Sonenshine DE. Overview: ticks as vectors of pathogens that cause disease in humans and animals. Front Biosci Landmark. 2008;13(18):6938-46. https://doi.org/ $10.2741 / 3200$.

2. Miller RJ, Davey RB, George JE. First Report of Organophosphate-resistant Boophilus microplus (Acari: Ixodidae) within the United States. J Med Entomol. 2005;42(5):912-7. https://doi.org/10.1093/jmedent/42.5.912.

3. de la Fuente J, Contreras M, Estrada-Pena A, Cabezas-Cruz A. Targeting a global health problem: Vaccine design and challenges for the control of tick-borne diseases. Vaccine. 2017;35(38):5089-94. https://doi.org/10. 1016/j.vaccine.2017.07.097.

4. Willadsen P, Wood GM, Riding GA. The relation between skin histamine concentration, histamine sensitivity, and the resistance of cattle to the tick, Boophilus microplus. Zeitschrift fur Parasitenkunde (Berlin, Germany). 1979:59(1):87-93. https://doi.org/10.1007/BF00927849.

5. Willadsen P, Kemp DH. Vaccination with "concealed" antigens for tick control. Parasitol Today. 1988;4(7):196-8. https://doi.org/10.1016/01694758(88)90084-1.

6. Murrell A, Barker SC. Synonymy of Boophilus Curtice, 1891 with Rhipicephalus Koch, 1844 (Acari: Ixodidae). Syst Parasitol. 2003;56(3):169-72. https://doi.org/10.1023/b:sypa.0000003802.36517.a0.

7. Willadsen P, Bird P, Cobon GS, Hungerford J. Commercialisation of a recombinant vaccine against Boophilus microplus. Parasitology. 1995;110(Suppl):S43-50. https://doi.org/10.1017/s0031182000001487.

8. Canales M, Enriquez A, Ramos E, Cabrera D, Dandie H, Soto A, et al. Largescale production in Pichia pastoris of the recombinant vaccine Gavac against cattle tick. Vaccine. 1997;15(4):414-22. https://doi.org/10.1016/ s0264-410x(96)00192-2.

9. de la Fuente J, Almazan C, Canales M, de la Lastra JM, Kocan KM, Willadsen $P$. A ten-year review of commercial vaccine performance for control of tick infestations on cattle. Anim Health Res Rev. 2007;8(1):23-8. https:// doi.org/10.1017/S1466252307001193.

10. Vargas M, Montero C, Sanchez D, Perez D, Valdes M, Alfonso A, et al. Two initial vaccinations with the Bm86-based GavacPlus vaccine against Rhipicephalus (Boophilus) microplus induce similar reproductive suppression to three initial vaccinations under production conditions. BMC Vet Res. 2010;61:43. https://doi.org/10.1186/1746-6148-6-43.

11. Pipano E, Alekceev E, Galker F, Fish L, Samish M, Shkap V. Immunity against Boophilus annulatus induced by the Bm86 (Tick-GARD) vaccine. Exp Appl Acarol. 2003;29(1-2):141-9. https://doi.org/10.1023/a:10242 46903197.

12. Willadsen P. Tick control: thoughts on a research agenda. Vet Parasitol 2006;138(1-2):161-8. https://doi.org/10.1016/j.vetpar.2006.01.050.

13. Almazan C, Moreno-Cantu O, Moreno-Cid JA, Galindo RC, Canales M, Villar $\mathrm{M}$, et al. Control of tick infestations in cattle vaccinated with bacterial membranes containing surface-exposed tick protective antigens. Vaccine. 2012;30(2):265-72. https://doi.org/10.1016/j.vaccine.2011.10.102.

14. Schetters T, Bishop R, Crampton M, Kopacek P, Lew-Tabor A, Maritz-Olivier $C$, et al. Cattle tick vaccine researchers join forces in CATVAC. Parasit Vectors. 2016:9:105. https://doi.org/10.1186/s13071-016-1386-8.

15. Campbell EM, Ball A, Hoppler S, Bowman AS. Invertebrate aquaporins: a review. J Comp Physiol [B]. 2008;178(8):935-55. https://doi.org/10.1007/ s00360-008-0288-2.

16. Sonenshine DE. Biology of ticks, vol. 1. New York: Oxford University Press; 1991.

17. Kotal J, Langhansova H, Lieskovska J, Andersen JF, Francischetti IM, Chavakis T, et al. Modulation of host immunity by tick saliva. J Proteomics. 2015;128:58-68. https://doi.org/10.1016/j.jprot.2015.07.005.

18. Schoeler GB, Wikel SK. Modulation of host immunity by haematophagous arthropods. Ann Trop Med Parasitol. 2001;95(8):755-71. https://doi.org/ 10.1080/0003498012011118. 
19. Guerrero FD, Miller RJ, Rousseau ME, Sunkara S, Quackenbush J, Lee Y, et al. BmiGl: a database of cDNAs expressed in Boophilus microplus, the tropical/southern cattle tick. Insect Biochem Mol Biol. 2005;35(6):585-95. https://doi.org/10.1016/j.ibmb.2005.01.020.

20. Wang M, Guerrero FD, Pertea G, Nene VM. Global comparative analysis of ESTs from the southern cattle tick, Rhipicephalus (Boophilus) microplus. BMC Genomics. 2007:8:1471-2164. https://doi.org/10.1186/ 1471-2164-8-368.

21. Guerrero FD, Andreotti R, Bendele KG, Cunha RC, Miller RJ, Yeater K, et al. Rhipicephalus (Boophilus) microplus aquaporin as an effective vaccine antigen to protect against cattle tick infestations. Parasit Vectors. 2014;7:475. https://doi.org/10.1186/s13071-014-0475-9.

22. Hussein HE, Scoles GA, Ueti MW, Suarez CE, Adham FK, Guerrero FD, et al. Targeted silencing of the Aquaporin 2 gene of Rhipicephalus (Boophilus) microplus reduces tick fitness. Parasit Vectors. 2015;8:618. https://doi.org/ 10.1186/s13071-015-1226-2.

23. Contreras M, de la Fuente J. Control of infestations by Ixodes ricinus tick larvae in rabbits vaccinated with aquaporin recombinant antigens. Vaccine. 2017;35(9):1323-8. https://doi.org/10.1016/j.vaccine.2017.01.052.

24. Evora PM, Sanches GS, Guerrero FD, Leon AP, Bechara GH. Immunogenic potential of Rhipicephalus (Boophilus) microplus aquaporin 1 against Rhipicephalus sanguineus in domestic dogs. Rev Bras Parasitol Vet. 2017;26(1):60-6. https://doi.org/10.1590/S1984-29612017005.

25. Howell JM, Ueti MW, Palmer GH, Scoles GA, Knowles DP. Transovarial Transmission Efficiency of Babesia bovis Tick Stages Acquired by Rhipicephalus (Boophilus) microplus during Acute Infection. J Clin Microbiol. 2007:45(2):426-31. https://doi.org/10.1128/jcm.01757-06.

26. Scoles GA, Ueti MW, Noh SM, Knowles DP, Palmer GH. Conservation of transmission phenotype of Anaplasma marginale (Rickettsiales: Anaplasmataceae) strains among Dermacentor and Rhipicephalus ticks (Acari: Ixodidae). J Med Entomol. 2007:44(3):484-91. https://doi.org/10.1093/ jmedent/44.3.484.

27. Ueti MW, Palmer GH, Kappmeyer LS, Scoles GA, Knowles DP. Expression of Equi Merozoite Antigen 2 during development of Babesia equi in the midgut and salivary gland of the vector tick Boophilus microplus. J Clin Microbiol. 2003;41(12):5803-9. https://doi.org/10.1128/JCM.41.12.58035809.2003.

28. Pastoret P-P, Griebel P, Bazin H, Govaerts A, editors. XIII - IMMUNOLOGY OF CATTLE. San Diego: Academic Press; 1998.

29. Wilkie BN. Review of bovine immunology for the veterinary practitioner. Can Vet J. 1974;15(9):243-8.

30. Sasaki M, Davis CL, Larson BL. Production and Turnover of IgG1 and IgG2 Immunoglobulins in the Bovine around Parturition. J Dairy Sci. 1976;59(12):2046-55. https://doi.org/10.3168/jds.S0022-0302(76)84486-4

31. Hurley WL, Theil PK. Perspectives on immunoglobulins in colostrum and milk. Nutrients. 2011;3(4):442-74. https://doi.org/10.3390/nu3040442.

32. Maritz-Olivier C, van Zyl W, Stutzer C. A systematic, functional genomics, and reverse vaccinology approach to the identification of vaccine candidates in the cattle tick Rhipicephalus microplus. Ticks Tick Borne Dis. 2012;3(3):179-87. https://doi.org/10.1016/j.ttbdis.2012.01.003.

33. Popara M, Villar M, Mateos-Hernandez L, de Mera IG, Marina A, del Valle $M$, et al. Lesser protein degradation machinery correlates with higher BM86 tick vaccine efficacy in Rhipicephalus annulatus when compared to Rhipicephalus microplus. Vaccine. 2013;31(42):4728-35. https://doi.org/10. 1016/j.vaccine.2013.08.031.

34. Aguirre Ade A, Lobo FP, Cunha RC, Garcia MV, Andreotti R. Design of the ATAQ peptide and its evaluation as an immunogen to develop a Rhipicephalus vaccine. Vet Parasitol. 2016;221:30-8. https://doi.org/10.1016/j. vetpar.2016.02.032.

35. Hughes EE, Gilleland HE Jr. Ability of synthetic peptides representing epitopes of outer membrane protein $\mathrm{F}$ of Pseudomonas aeruginosa to afford protection against $P$. aeruginosa infection in a murine acute pneumonia model. Vaccine. 1995;13(18):1750-3. https://doi.org/10.1016/ 0264-410x(95)00166-x.

36. Dominguez M, Echaide I, Echaide ST, Mosqueda J, Cetra B, Suarez CE, et al. In silico predicted conserved B-cell epitopes in the merozoite surface antigen-2 family of $B$ bovis are neutralization sensitive. Vet Parasitol. 2010;167(2-4):216-26. https://doi.org/10.1016/j.vetpar.2009.09.023.

37. Willadsen P. Antigen cocktails: valid hypothesis or unsubstantiated hope? Trends Parasitol. 2008;24(4):164-7. https://doi.org/10.1016/j.pt.2008.01. 005.
38. Ndawula C, Tabor AE. Cocktail anti-tick vaccines: the unforeseen constraints and approaches toward enhanced efficacies. Vaccines. 2020;8(3):457. https://doi.org/10.3390/vaccines8030457.

39. Alzan HF, Cooke BM, Suarez CE. Transgenic Babesia bovis lacking 6-Cys sexual-stage genes as the foundation for non-transmissible live vaccines against bovine babesiosis. Ticks Tick Borne Dis. 2019;10(3):722-8. https:// doi.org/10.1016/j.ttbdis.2019.01.006.

40. Suarez CE, Noh S. Emerging perspectives in the research of bovine babesiosis and anaplasmosis. Vet Parasitol. 2011;180(1-2):109-25. https://doi. org/10.1016/j.vetpar.2011.05.032.

\section{Publisher's Note}

Springer Nature remains neutral with regard to jurisdictional claims in published maps and institutional affiliations.
Ready to submit your research? Choose BMC and benefit from:

- fast, convenient online submission

- thorough peer review by experienced researchers in your field

- rapid publication on acceptance

- support for research data, including large and complex data types

- gold Open Access which fosters wider collaboration and increased citations

- maximum visibility for your research: over $100 \mathrm{M}$ website views per year

At BMC, research is always in progress.

Learn more biomedcentral.com/submissions 